\title{
Improving Cost Efficiency of Mango Orchards through Application of Data Envelopment Analysis (DEA)
}

\author{
Anil Kumar Verma ${ }^{1 *}$, A.K.A. Lawrence ${ }^{2}$, Ashok Tripathi ${ }^{3}$ and Surendra Pal ${ }^{4}$
}

Department of Farm Machinery and Power Engineering, Vaugh Institute of Agricultural Engineering and Technology, Sam Higginbottom University of Agriculture, Technology \& Sciences (formerly Allahabad Agriculture Institute), Allahabad (U.P), India

*Corresponding author

\begin{abstract}
A B S T R A C T
\section{Keywords}

Data envelopment analysis,

Optimization, Cost

saving, Technical efficiency; Mango

\section{Article Info}

Accepted:

17 November 2018

Available Online:

10 December 2018

In this study a non-parametric method of data envelopment analysis (DEA) was applied to analyze the cost efficiency of mango orchardist, in order to optimize the input costs for mango production in Mall-Malihabad Mango belt of Lucknow district (Uttar Pradesh). Data were collected using face-to-face questionnaire from 50 orchards in ten villages of this belt. The DEA CCR and BCC models were used based on seven input costs including human labour, machinery rent, FYM, water for irrigation, pesticide, diesel and electricity and single output of mango yield. The technical, pure technical and scale efficiencies of farmers were calculated as $0.662,0.965$ and 0.684 respectively. Total optimum cost requirement was found to be about Rs $26017.28 \mathrm{INR} \mathrm{ha}^{-1}$, showing that $10.2 \%$ of input costs could be saved if the orchardists follow the results recommended by this study. Moreover the contribution of chemical (Pesticide) input from total cost saving was $62.46 \%$ which was the highest share followed by FYM and machinery input costs. Optimization of input costs use improved the benefit/cost ratio, net return and productivity by $32.12 \%$, $28.24 \%$ and $29.72 \%$ respectively.
\end{abstract}

\section{Introduction}

The Mango (Mangifera indica) is the most important and highly consumed fruit of India. Mango is grown in almost all over the world, like China, India, Pakistan, Bangladesh, Philippine, Burma, Thailand, Malaya, Mexico, Brazil, USA, etc. The cultivation area of the mango is largest among the world i.e. 2,263 thousand ha with a production of 19.68 million tons (MT). The productivity was 8.7 tons $\mathrm{ha}^{-1}$ which is higher to the global productivity (7.51tons ha ${ }^{-1}$ ). However, it is far below the other less mango producing countries such as Brazil (15.83tonsha ${ }^{-1}$ ), Pakistan (10.62 tons/ha). The rising cost of production and depleting energy sources one of the top concerns is maximization of productivity per unit area with minimum input cost. It has been observed that the average yield of the mango can be increased through proper adoption good agricultural practices viz., optimum application of tillage practices, irrigation, fertilizers and chemicals. Orchardists in general, use resources excessively and inefficiently particularly, 
when they are priced relatively low. Also when endowed with rich natural resources, they use other inputs also in excess expecting to reap higher yield. Thus their use is more, resulting in higher cost of production and wastage of resources. It was also pointed out that there exists potential to reduce cost of production by avoiding irrational use of farm inputs (Anon., 1990).

Data Envelopment Analysis (DEA) a nonparametric technique for efficiency evaluation, bench marking and optimal use of resources for savings of cost and energy in crop production system are widely applied by researchers all over world. (Kazim Baris et al., (2012); Mobtaker et al., (2011) analyse the cost efficiency of barley farmers in Iran and improve the benefit /cost ratio $11.61 \%$ and net return by $10.25 \%$. The similar result was found by Mousavi-Avval et al., (2011b) in apple production in Tehran, they reported that cost of production decrease by $7.99 \%$ and improvement in benefit /cost ratio and productivity by $8.06 \%$ and $8.7 \%$ respectively. Mohammadi et al., (2010) also indicated in their economical analysis results obtain by using DEA analysis which showed that a decreases in the total costs of production by $4.91 \%$; and the benefit - cost ratio and productivity increased by $5.15 \%$ and $5.19 \%$, respectively. Based on literature, the study was focused on the application of DEA to optimize the technical efficiency, pure technical and scale efficiencies of mango orchards to reduce cost of production in mango production.

\section{Materials and Methods}

The Mall - Malihabad mango belt is located in the Lucknow district of Utter Pradesh of India; within $26.92-27.02^{0} \mathrm{~N}$ and 80.7076 to $80.7367^{\circ} \mathrm{E}$. the average rainfall is $1014 \mathrm{~mm}$ and altitude above sea level is 128 meter with average high and low annual temperature of
$43^{0} \mathrm{C}$ and $5^{\circ} \mathrm{C}$, respectively (Rajan et al., (2016). The data used in this study, has collected form 50 mango orchards by using face to face questionnaire in 2016. Sample orchards were randomly selected from the ten villages in the study area by using stratified random sampling technique. The data included amount of input costs, used in different operations (tillage, fertilizer application including FYM, irrigation, plant protection and harvesting) for mango production such as human labour, diesel and machinery rent, fertilizers, pesticide, fungicide and water for irrigation, and the yield as an output. Based on prevailing market rates in study area, total cost of inputs per hectare was calculated by following equations.

1. Machinery cost $=$ (tractor and machinery hrs ha ${ }^{-1}$ used in tillage $x$ rent per hr) + (tractor and machinery hrs ha ${ }^{-1}$ used for spraying of chemical in plant protection) $\times$ rent INR per hrs

2. Human Labour cost $=$ [Total labour hrs used per ha in (tillage + FYM + Chemical fertilizer + Irrigation + plant protection + harvesting)] $\times$ (rate of labour INR per day/ 8)

3. $\quad$ FYM cost $=$ Total FYM used $\mathrm{kg} \mathrm{ha}^{-1} \times$ rate of FYM

4. Fuel cost (Diesel) $=[$ Total diesel consume per hectare for (tillage + plant protection + engines (irrigation) $] \times$ rate of diesel INRliter ${ }^{-1}$

5. Electricity cost $=$ (Electricity consumption per ha) $\times$ rate of electricity INRkwh ${ }^{-1}$

6. Water cost $=$ [water consume (plant protection + irrigation) in $\left.\mathrm{M}^{3}\right] \times$ rate $\operatorname{INR}\left(\mathrm{M}^{3}\right)^{-1}$ 
Table 1 showed the inputs and output costs used in mango production on, there was a wide variation in the quantity of input costs and output for mango production; indicating that there is ample scope for improving the cost efficiency of mango production in the area. The DEA (Non Parametric method) technique suggested by Charnes et al., (1978) and Banker et al., (1984) were used to evaluate the technical, pure technical and scale efficiencies of individual orchards which use similar inputs, produce the same product (mango) and operate in similar condition.

DEA technique was used for evaluated the relative performance of orchards in terms of cost efficiency, cost saving and cost saving targets. Cost efficiency can be expressed generally by the ratio of sum of the weighted outputs to sum of weighted inputs (Nassiri and

$$
\text { Maximize } \theta=\sum_{r=1}^{n} u_{r} y_{r i}
$$

Subjected to

(i)

$$
\begin{aligned}
& \sum_{r=1}^{n} u_{r} y_{r i}-\sum_{s=1}^{n} v_{s} x_{s j} \leq 0 \\
& \sum_{s=1}^{n} v_{s} x_{s j}=1 \\
& u_{r} \geq 0, v_{s} \geq 0 \text { and }(i \text { and } j=(5)
\end{aligned}
$$
Charnes et al., in 1978:

where, $u_{r}$, is the weight given to output $n ; y_{r}$, the amount of output $n ; v_{s}$, the weight given to input $n ; x_{s}$, the amount of input $n ; r$, number of outputs $(\mathrm{r}=1,2, \ldots, \mathrm{n}) ; s$, number of inputs ( $\mathrm{s}$ $=1,2, . ., \mathrm{m})$ and $j$, represents $j$ th of orchards $(\mathrm{j}$ $=1,2, \ldots, \mathrm{k}$ ). To solve Eq. (1), Linear Program (LP) was used, which developed by

Subjected to (i)

$u_{r} \geq 0, v_{s} \geq 0$ and ( $i$ and $j=1,2,3,4, \ldots . k$ )

where, $\theta$ is the cost efficiency and $i$ represents $i^{\text {th }}$ orchard (it will be considered as fixed in Eqs. (2) and (4) while $j$ increases in Eq. (3). The above CCR DAE model is a linear programming model which assumes that there is no significant relation between the scale of operations and efficiency (Avkiran, 2001). So the large producers are just as efficient as small ones in converting inputs to output. Pure cost efficiency is the cost efficiency under variable return to scale condition and calculated by another model called BCC model of DEA suggested by Bankers et al., (1984) Pure cost efficiency could separate both cost and scale efficiencies. It can be expressed by Dual Linear Program (DLP) as follows 
Maximize

Subjected to

$$
Z=u y_{i}-u_{i}
$$

Where, $z$ and $u_{0}$ are scalar and free in sign. $u$ (output) and $v$ (inputs) are weight matrixes, and $Y$ and $X$ are corresponding output and input matrixes, respectively. The letters $x_{i}$ and $y_{i}$ refer to the inputs and output of $i$ th orchard. The relation among the scale efficiency, cost efficiency and pure cost efficiency can be expressed as (Chauhan et al., 2006):

Scale efficiency $=\frac{\text { cost efficiency }}{\text { Pure cost efficiency }}$

The above model was solved by using (Max DEA6.13) basic software. The results of standard DEA models separate efficient and inefficient ones. In the analysis of efficient and inefficient orchards the cost saving target ratio (CSTR) index was used which represents the inefficiency level for each orchards with respect to cost use. The formula is as follow (Hu and Kao, 2007):

$$
\text { CSTR }_{j}=\frac{(\text { cost saving Target })_{j}}{(\text { Actual input cost })_{j}}
$$

Where cost saving target is the total reducing amount of input costs that could be saved without decreasing output level and $j$ represents $j$ th orchard. The minimal value of cost saving target is zero, so the value of CSTR will be between zero and unity.

\section{Results and Discussion}

The results of BCC and CCR DEA models are illustrated in Figure 1. The results revealed that, among the total of 50 orchardists considered for the analysis, 41 farmers (61.19\%) had the pure technical efficiency score of 1 . Also, from the pure technically efficient farmers 16 farmers $(23.88 \%)$ had a technical efficiency score of 1 . From efficient farmers 16 were the fully efficient farmers in both the technical and pure technical efficiency scores; indicating that they were globally efficient and operated at the most productive scale size of production; however, the remaining of 25 pure technically efficient farmers were only locally efficient ones; it was due to their disadvantageous conditions of scale size. From inefficient farmers 12 and 17 have their technical and pure technical efficiency scores in range of $0.9-0.99$. It means that the farmers should be able to produce the same level of output using their efficiency score of their current level of input costs when compared to its benchmark which are constructed from the best performers with similar characteristics. From efficient farmers 7 ones had a scale efficiency of unity.

The summarized statistics for the three estimated measures of efficiency are presented in Table 2. The results revealed that the average values of cost, pure cost and scale efficiency scores were $0.662,0.965$ and 0.684 , respectively. Moreover the cost efficiency varied from 0.433 to 1 , with the standard deviation of 0.174 , which was the highest variation between those of pure cost and scale efficiencies. The wide variation in the cost efficiency of orchards implies that all the orchards were not fully aware of the right 
production techniques or did not apply them at the proper time in the optimum quantity.

The optimum cost requirement and cost saving of various farm inputs for mango production based on the results of BCC model are given in Table 3. The results revealed that the total production cost in optimum condition was $26017.28 \mathrm{INR} \mathrm{ha}^{-1}$; so the total cost of production in present condition (28964.21 INR ha ${ }^{-1}$ ) could be saved by $10.17 \%$. This mean that by following the recommendations resulted from this study, on average, about 2946.93INR $\mathrm{ha}^{-1}$ of total production cost could be saved while holding the constant output level of mango yield. The results of ESTR calculation showed that, $17.50 \%$ from total FYM and fertilizer, $13.01 \%$ chemical (plant protection), 8.69\% from water for irrigation and $15.70 \%$ (7.4+8.3) from machinery rent and diesel cost could be saved. In the last column of Table 3 the shares of the various sources from total input costs saving are presented.

Table.1 Amount of input output cost of mango production

\begin{tabular}{|l|l|r|r|r|r|}
\hline $\begin{array}{l}\text { Sr. } \\
\text { No. }\end{array}$ & $\begin{array}{l}\text { Total input } \\
\text { cost (INRha }\end{array}$ & \multicolumn{1}{l|}{ SD } & \multicolumn{1}{l|}{ Min } & \multicolumn{1}{l|}{ Max } \\
\hline & Inputs & 3438.27 & 302.39 & 2942.76 & 4222.38 \\
\hline Machinery & 4732.24 & 608.57 & 4194.00 & 6552.38 \\
\hline Human labour & 1981.43 & 426.03 & 1457.50 & 2800.00 \\
\hline FYM & 2478.49 & 252.15 & 2065.80 & 3066.25 \\
\hline Diesel & 1810.70 & 454.33 & 971.00 & 2089.00 \\
\hline Electricity & 377.68 & 46.38 & 282.30 & 462.60 \\
\hline Water & 14145.41 & 2391.29 & 9724.00 & 19430.99 \\
\hline Chemical & 28964.21 & 3371.10 & 22870.51 & 36728.98 \\
\hline Total production cost & & & & \\
\hline Output & 113629.24 & 40027.69 & 75400.00 & 298250.00 \\
\hline Total output cost & & & & \\
\hline
\end{tabular}

Table.2 Average cost, pure cost and scale efficiency of mango orchardists

\begin{tabular}{|l|c|c|c|c|c|}
\hline \multicolumn{1}{|c|}{ Particular } & $\begin{array}{c}\text { \% of efficient } \\
\text { orchards }\end{array}$ & Mean & SD & Min & Max \\
\hline Cost efficiency & 12 & 0.662 & 0.174 & 0.433 & 1.000 \\
\hline Pure cost efficiency & 36 & 0.965 & 0.036 & 0.872 & 1.000 \\
\hline Scale efficiency & 12 & 0.684 & 0.172 & 0.455 & 1.000 \\
\hline
\end{tabular}


Table.3 Optimum cost requirement and cost saving for mango production

\begin{tabular}{|c|l|c|c|c|c|}
\hline $\begin{array}{c}\text { Sr. } \\
\text { No }\end{array}$ & \multicolumn{1}{|c|}{ Inputs } & $\begin{array}{c}\text { Optimum cost } \\
\text { (INR ha }^{-1} \text { ) }\end{array}$ & $\begin{array}{c}\text { Cost saving } \\
\left.\text { (INR ha }^{-1}\right)\end{array}$ & $\begin{array}{c}\text { Cost saving } \\
\text { \% }\end{array}$ & $\begin{array}{c}\text { contribution to the } \\
\text { total cost saving }\end{array}$ \\
\hline $\mathbf{1 .}$ & MC & 3153.032 & 285.23 & 8.30 & 9.68 \\
\hline $\mathbf{2 .}$ & LABOUR C & 4552.154 & 180.09 & 3.81 & 6.11 \\
\hline $\mathbf{3 .}$ & FUEL & 2295.141 & 183.34 & 7.40 & 6.22 \\
\hline $\mathbf{4 .}$ & ELECTRICITY & 1732.548 & 78.15 & 4.32 & 2.65 \\
\hline $\mathbf{5 .}$ & FYM/ fertilizer & 1634.723 & 346.71 & 17.50 & 11.77 \\
\hline $\mathbf{6 .}$ & CHEMICAL & 12304.84 & 1840.57 & 13.01 & 62.46 \\
\hline $\mathbf{7 .}$ & WATER & 344.8382 & 32.84 & 8.69 & 1.11 \\
\hline & Total production cost & 26017.28 & 2946.93 & 10.17 & 100.00 \\
\hline & Gross return & 134760.4 & -21131.17 & & \\
\hline
\end{tabular}

Table.4 Improvement of economical indices for mango production

\begin{tabular}{|l|l|l|l|l|}
\hline Items & Units & Present quantity & Optimum & Difference \% \\
\hline Benefit cost ratio & - & 3.94 & 5.20 & 32.12 \\
\hline Net return & INR ha $^{-1}$ & 84665.03 & 108743.13 & 28.44 \\
\hline Productivity & $\mathrm{Kg} \mathrm{INR}^{-1}$ & 0.40 & 0.52 & 29.70 \\
\hline Total production & $\mathrm{Kg} \mathrm{ha}^{-1}$ & 11646.60 & 13476.04 & 15.71 \\
\hline
\end{tabular}

Fig 1: Effeciency score distribution of orchards

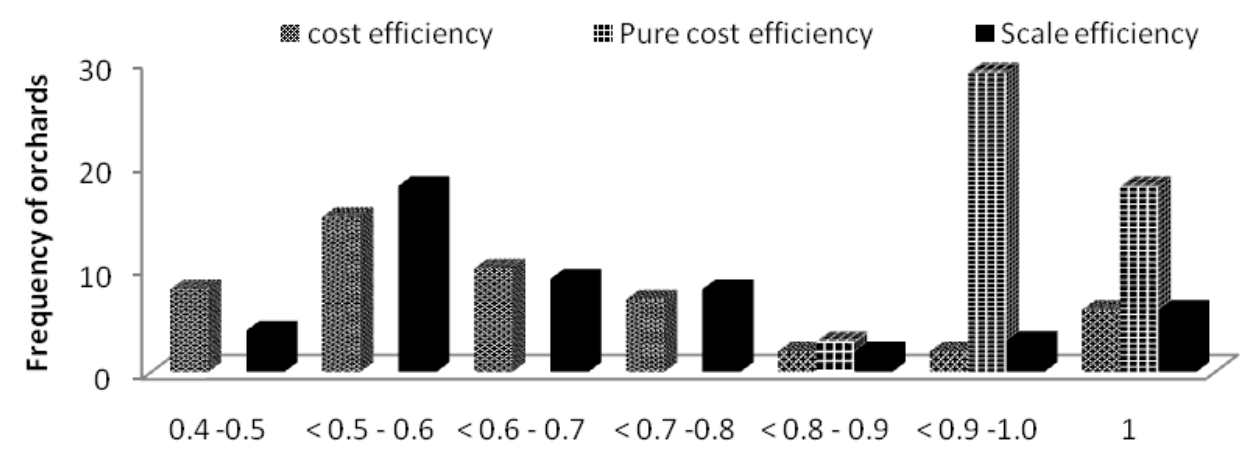

Eficiency score (decimal)

Results revealed that the highest contribution to the total cost saving was $63.77 \%$ for water for irrigation cost. This indicates that in the case of water for irrigation cost, there is a greater scope to decrease the production cost. It was followed by fertilizers and diesel and machinery rent cost by $11.72 \%$ and $8.78 \%$ respectively. Also the shares of land rent and biocides costs were relatively low.
The improvements in economical indices for mango production are presented in Table 4. The average benefit/cost ratio was improved from 3.94 to 5.2, showing an improvement of $32.12 \%$. Also, net return and productivity in target conditions were improved $28.44 \%$ and $29.70 \%$, respectively. 
The objective of this study was to analyse the cost efficiency of orchards and identify the efficient and inefficient orchards by apply the non-parametric method of data envelopment analysis (DEA), for mango production in Mall - Malihabad region of Utter Pradesh India. The method was applied considering based on seven input costs including human labour wages, machinery rent, water for irrigation, fertilizers, FYM, chemical for plant protection and fuel (diesel and electricity) and single output of mango yield. The following results were concluded by this study:

Among the total of 50 orchards, considered for the analysis, $12 \%$ and $36 \%$ were found to be cost and pure cost efficient, respectively.

The cost, pure cost and scale efficiencies of farmers were calculated as $0.662,0.965$ and 0.684 , respectively.

Total optimum cost requirement was found to be about 26017.28 $\mathrm{INRha}^{-1}$; showing that $10.17 \%$ of input costs could be saved if the farmers follow the results recommended by this study.

Optimization of cost use improved the benefit/cost ratio, productivity and net return by $32.12 \%, 29.70 \%$ and $28.44 \%$, respectively.

\section{References}

Avkiran. N.K., (2001), Investigating technical and scale efficiencies of Australian Universities through data envelopment analysis, Socio-Economic Planning Sciences, 35(1), pp 57-80.

Banker. R.D., Charnes. A., Cooper. W. W. (1984). Some models for estimating technical and scale inefficiencies in data envelopment analysis. Management Science, 30(9), 10781092.

Charnes. A., Cooper. W.W., Rhodes. E.,
(1978), Measuring the efficiency of decision making units, European Journal of Operational Research, 2, pp 429-444.

Chauhan. N.S., Mohapatra. P.K.J., Pandey. K.P., (2006), Improving energy productivity in paddy production through benchmarking-an application of data envelopment analysis, Energy Conversion Management, 47(9-10), pp 1063-1085.

http//maxdea.com, MaxDEA Ultra 6.15

Hu. J.L., Kao. C.H., (2007), Efficient energysaving targets for APEC economies, Energy Policy, 35(1), pp 373-382.

Kazim Baris Atici and Victor V. Podinovski, (2012) "A Review of Data Envelopment Analysis Studies In Agriculture" Warwick Business School, University of Warwick, CV4 7AL, Coventry, United Kingdom

Mobtaker. H.G. (2011), "Application of data envelopment analysis (DEA) to improve cost efficiency of barley" International journal of applied engineering research, Dindigul. vol 2, No 2, pp 578-586.

Mohammadi. A., Rafiee. S.H., Mohtasebi. S.S., Mousavi-Avval. S.H., Rafiee. H., (2011), Energy efficiency improvement and input cost saving in kiwifruit production using Data Envelopment Analysis approach, Renewable Energy, 36, pp 2573-2579.

Mousavi-Avval. S.H., Rafiee. S., Mohammadi. A., (2011b), Optimization of energy consumption and input costs for apple production in Iran using data envelopment analysis, Energy, 36, pp 909-916.

Namdari. M., 2011, Energy use and cost analysis of watermelon production under different farming technologies in Iran, International Journal of Environmental Sciences, 1(6), pp 1144-1153. 
Nassiri. S.M., Singh. S., (2009), Study on energy use efficiency for paddy crop using data envelopment analysis (DEA) technique, Applied Energy, 86(7), pp 1320-1325.

Rajan, S.; Lamers, H.A.H.; Lal, B. (2016) A set of interconnected practices which enhances and conserve mango diversity in Malihabad, India. In: Sthapit, B. (et al., (eds.)) Tropical fruit tree diversity: good practices for in situ and on-farm conservation. Abingdon, Oxon (UK): Routledge, p. 173-183. ISBN: 978-1-138-78128-3.

Singh, M. and Maurya, V.N. 1986. Performance of some late mango varieties in Gangetic plains of north India. Punjab Hort. J., 26(1): 8-12.

\section{How to cite this article:}

Anil Kumar Verma, A.K.A. Lawrence, Ashok Tripathi and Surendra Pal. 2018. Improving Cost Efficiency of Mango Orchards through Application of Data Envelopment Analysis (DEA). Int.J.Curr.Microbiol.App.Sci. 7(12): 2468-2475. doi: https://doi.org/10.20546/ijcmas.2018.712.280 